\title{
Factors Influencing CEO Compensation in US Telecommunication Industry
}

\author{
Garanina Tatiana ${ }^{a^{*}}$, Ladyzhenko Iuliiab \\ a* Senior Lecturer, Department of Finance and Accounting, Graduate School of Management, St. Petersburg University. \\ ${ }^{*}$ Corresponding author's e-mail: garanina@gsom.pu.ru. \\ b Graduate, Master in International Business Program, Graduate School of Management, St. Petersburg University.
}

\section{H I G H L I G H T S:}

1. Relationship between a set of factors and executive compensation system is analyzed.

2. Executive compensation is positively related to revenue and earnings per share.

3. Executive compensation is unrelated to return on net assets and market value added.

4. Executive decisions to maximize the shareholder value influence the compensation.

5. Executive compensation system should be used as a mechanism to eliminate agency costs.

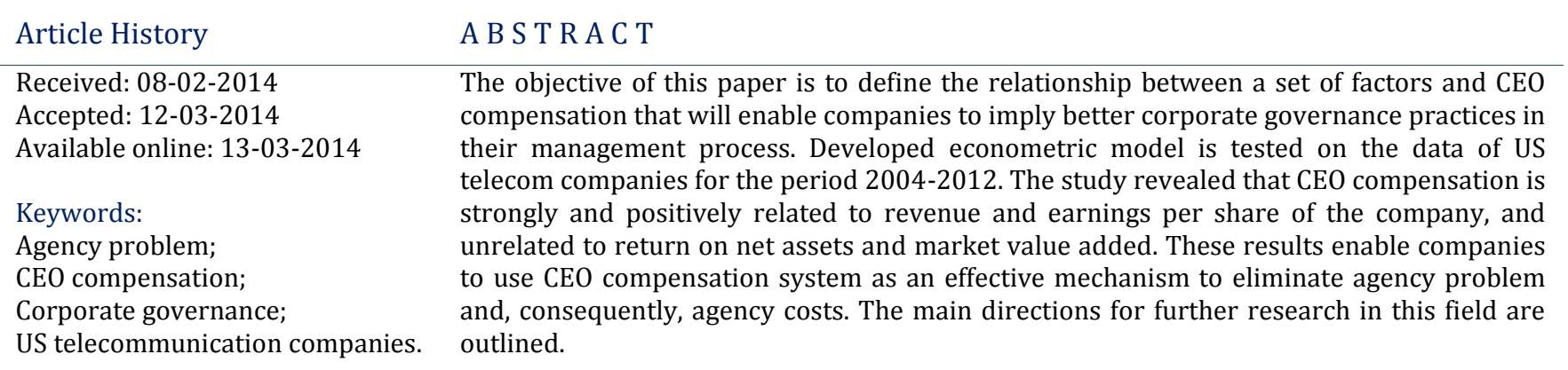

JEL Classification:

G32; G34; J33.

DOI: http://dx.doi.org/10.18533/jefs.v2i01.127

(C) 2014 The Authors. This is an open access article under the terms of the Creative Commons Attribution License 4.0, which allows use, distribution and reproduction in any medium, provided the original work is properly cited.

\subsection{Introduction}

The importance of corporate governance is growing in the organizations all over the world. Together with huge benefits, separation of ownership and control revealed some problems. One of them is conflict of interest between managers and owners which may jeopardize the business of the company. Therefore, companies strive for good corporate governance practices as a yardstick for strategic development of a company.

Few issues in the history of a modern corporation have attracted a lot of attention to executive compensation as an effective mechanism of corporate governance and, in particular, of dealing with the agency problem. Properly awarded executives in most cases do not have an incentive to operate in self-interest and act irresponsibly, but to maximize the shareholder's value.

The objective of this paper is to identify the set of factors that influence the CEO compensation on the example of US telecommunications industry. Evidence on this relation will enhance the knowledge on the role of different factors that may influence the managerial performance and help identify the trends of organizational performance for all the firms in the industry. There are a lot of papers, that will be examined further, that analyze different industries 
from the point of view of compensation system. In this paper we decided to focus on telecommunication industry as previous researchers did not analyze this industry in details and that brings novelty to the paper. We will define the main drivers that influence CEO compensation in particularly for US telecom companies. On the base of the obtained results, in the conclusion section we will develop a set of recommendations specifically for this industry that lead to decrease of the agency problem that is faced by managers.

In this paper managerial pay is defined as the sum of salary, bonus, value of restricted stock granted (stock awards), value of stock options granted (option awards), long-term incentive program, change in pension value and all over compensation; executives are defined as individuals with the title of CEO (Chief Executive Officer).

It is assumed that the evidence of this research will fulfill the literature gap that exists now in the field of the relation between compensation and accounting and market measures; will enhance the knowledge on the role of different factors that may influence the managerial performance and help identify the trends of organizational performance for all the firms in telecommunications industry.

The paper is organized in the following way. The first part provides a theoretical background on the topic. The second part represents methodology overview and the regression model used in the paper. In the last part the conclusions and managerial applications are discussed. Literature review on the topic will show that the payperformance topic has been investigated a lot from different perspectives.

\subsection{Literature on corporate performance valuation}

Nowadays a lot of attention has been paid to executive compensation as to an effective mechanism of corporate governance and in particular of agency problem. Properly awarded executive in most cases does not have an incentive to operate in self-interest and act irresponsibly, but maximization of the company's value. Thus the main objective of this paper is to identify the set of factors that influence the executive compensation on the example of US telecommunications industry.

Up to the present moment huge amount of researches investigated that pay-performance relationship is connected with the fact that there is no common approach which could enable to evaluate the quality of corporate governance in a company. Thus, all the existed research could be divided into four main groups.

The first group involves the studies where for evaluation of the quality of work we consider one of the parameters: frequency of board meetings, quantity and share of independent directors. For estimation of the results in this group accounting (return on equity, return on assets and return on sales) and market (Tobin's Q coefficient, market-to-book and market-to-sales ratio) measures were used. Hermalin and Weisbach (1988), Lawrence and Stapledon (1997), Mehran (1995), Ferris, Murali and Pritchard (2003), in their works did not find statistically sufficient correlation between the quality of corporate governance from the perspective of share of independent directors and performance of the company. Hermalin and Weisbach (1988) came to a conclusion that there is no correlation between the share of independent directors in the board and market and accounting measures; Ferris, Murali and Pritchard (2003) did not find correlation between the share of independent directors in the board and market-to-book ratio; Hermalin and Weisbach (1988) did not find correlation between the share of independent directors in the board and Tobin's $Q$.

On the contrary some of the studies did find the correlation between the quality of corporate governance with accounting and market measures: both negative and positive. For instance, Rosenshtein and Wyatt (1990) indicated the fact that addition an independent director to the board boosts the share price at $0.2 \%$. Instead in some works authors found negative correlation between the share of independent directors in the board and Tobin's Q coefficient that is also highlighted in Bayburina and Shustrova (2008).

The second group comprises of the researches where the corporate governance rating (integral parameter) was used to evaluate the top-managers' quality of work. Here the market and accounting measures are supplemented by cost measures such as market capitalization, economic value added (EVA) and market value added (MVA). The summary is provided by Adjaodi, Zeghal and Andaleeb (2007) where it is shown that the results of these studies proved the existence of positive statistically sufficient correlation between EVA and corporate governance rating.

Studies that are based on the same approaches as those of the second group are included into the third group. The main difference between the groups is that here we consider not only the interrelation between the quality of corporate governance and company's performance, but also the link with every single element which is involved in the rating of corporate governance. This group is also based on market, accounting and cost measures. One of the key works of this group of studies is the one of Black, Jang, Kim (2005) in which they declared statistically sufficient correlation between corporate governance rating and Tobin's $Q$ coefficient. 
The forth group is the most valuable for current empiric research. It considers the correlation between the executive compensation and performance of the company. The researches include analysis which is also based on market, accounting and cost measures. In this group the researches investigate the influence of economic value added and market value added on the executive compensation.

The field really took off with the work of Murphy (1985) who considered the panel data on compensation of individual executives and performance over the number of years. He introduced "fixed-effects models" and considered the effects of six performance-sensitive components of remuneration (salary, bonus, option awards, deferred compensation, value of stock options, total compensation). Overall he documented that compensation is strongly positively related to corporate performance as measured by shareholder return and growth in firm sales. Hall and Liebman (1998) conducted a research identifying the strong link between wealth and firm performance. They also pointed out that the relationship is very sensitive so that small changes in performance can have large effects on the lifetime wealth of an executive (Florin, Hallock and Webber 2010).

Another perspective on the role of executive compensation in agency theory is considered in the works of Hambrick and Finkelstein (1995). They argue that the relationship between the compensation and company's performance is necessary for explaining the hidden parts of compensation. Beer and Katz (1998) revealed the results of research devoted to executive compensation. The research documented that the average salary in American corporations is much higher than the remuneration in Asian or European ones and has a positive impact on managers' behavior. For current research the peculiarities of American companies are of great importance. It is unique due to the fact that option awards are the biggest part of compensation. That means that the level of executive remuneration is much higher than the level of general employee.

From the recent researches on the topic of executive compensation it is worth mentioning the work of Bebchuk and Fried (2004). In their paper they tried to execute the relations between pay and performance. They presume that the compensation is the product of arm'-length contracting. That implies that principal and agent have only professional relationship when reaching the common ground in terms of aligning their interests. Taking it into consideration, the academics assumed that executive compensation arrangements will tend to increase value (Junarsin, 2011). However, they stated that this compensation strongly affects by managerial power, but not by their performance. Thus, the paper's main claim is to develop some improvements in order to avoid biased compensation practice.

Later, a study was conducted by Bebchuk and Grinstein (2005). They examined the extent to which increase in the compensation could be affected by company's performance. The results of this paper revealed that the company's size and performance are not the only factors which influence the executive's compensation. They claim that these two factors could explain only $40 \%$ of the compensation. Thus, the authors identified that another $40 \%$ of CEO's remuneration is accumulated with a help of including equity-based measures into the package.

Fatemi, Desay and Katz (2002) demonstrated the positive correlation between EVA and executive compensation. The same result was got in the study of Baum, Sarver and Strickland (2004). Their analysis revealed that MVA has stronger influence on executive compensation than does EVA. However the results of these studies pointed out that if to evaluate a company with a help of MVA, than it is evidently that managers have to get higher remuneration. But, apparently, that those mechanisms which will increase MVA will also will enable managers to "play with the value" in order to get higher compensation. This means that the compensation will increase, but only in short run while in long ran it undermines the company's financial stability.

All these results enabled researches to do a major conclusion that the more executive compensation is dependent on the performance of the company. Most studies that explore the pay-performance relationship used the accounting-based measures of corporate performance, i.e. ROA or ROE. However the trend is shifting nowadays and more and more studies use risk adjusted firm-performance - market value added. Corporate governance is of paramount importance for every organization. History has revealed that there is never-ending evolution of corporate governance and its fundamental theories. Companies strive for good corporate governance practices as a yardstick for strategic development of a company.

One of important instruments of corporate governance is executive compensation. Identifying the factors that mostly contribute to the growth of executive pay could enable to develop an effective package which will not let managers even think about operating only in self-interests. This paper will answer several research questions that fulfill the literature gap in understanding the role of different factors that may influence the managerial performance and help identify the trends of organizational performance in US telecommunications industry.

\subsection{Research methodology}


In the paper the following research questions were set up according to previous literature review:

(a) What performance metrics and financial ratios are used in evaluating pay-performance relationship? - We study different components of the executive pay and determine the financial ratios that can at most contribute to the full coverage of current investigation. The crucial point here is that how exactly to define performance. There are several ways to do it, but the most commonly used accounting-based measures (for example, return on assets, return on equity, return on common stock, shareholder wealth).

(b) How various performance measures are used in a particular industry? - It is important to research an industry as far as it may have specific influence on the results of the work. The current research is based on the evidence of telecommunication industry, thus we will explore it in more detail to find the peculiarities that may influence the changes in the industry.

(c) Is there a correlation between firm performance and managerial pay? - This question is the initial impulse for this paper. In case of existence of relationship we will consider the type of correlation, whether it is negative or positive.

(d) What is the relationship between top management compensation and measure of risk-adjusted firm performance - market value added (MVA)? - We seek to explore empirically the relationships between executive compensation and MVA - the reasonable proxy for the measurement of owner wealth maximization. The answer to this question is the addition of MVA into the model.

Based on these research questions and the extensive literature review the following hypotheses have been formulated.

\section{H1. The higher is the company's revenue, the greater is the remuneration of the executive.}

Most researches which were conducted in the last decades constitute the existence of positive correlation between the company's revenue and the executive compensation, particularly in the form of option awards; but it is statistically insufficient. On the contrary to these results, the work of Hall and Liebman (1998) suggested that even small changes in performance can have very large effects on the lifetime of wealth execution. This choice of performance measure enables us to set a second hypothesis.

H2. The higher is ROA, the greater is the remuneration of the executive.

In the current research we are inclined to believe that ROA will be more suitable for the telecommunication industry as an accounting measure for performance because of its availability and straightforward interpretation and construction. We will consider Return on Assets to affect the remuneration of the executive only to the extent that it us a proxy for unobservable managerial effort on productivity. Therefore we may observe the positive trend as it was found in most empirical studies on this topic.

\section{H3. The higher are earnings per share, the greater is the remuneration of the executive.}

To set this hypothesis regarding the executive performance we explored different economic or market metrics. The most common measure here is earnings per share. A lot of studies suggested using this metrics. We also prefer it as it is the direct measure of the progress of CEO important responsibility for a corporation - to maximize the shareholders benefit. This hypothesis together with $\mathrm{H} 1$ and $\mathrm{H} 2$ could contribute to the conclusion of the degree accounting and market measures influence the company's performance.

\section{H4. The higher is the level of risk borne by the firm, the greater is the executive compensation.}

This hypothesis was formulated since in the current research we add risk to the equation of pay-performance relationship. We expect a positive relationship between executive compensation and company performance which is measured in the context of value creation for the owners of the company using MVA. In the times of globalization managers will expect their compensation to contain the premium for risk. This trend leads to a positive relationship between compensation and the risk borne by the company.

These hypotheses will be verified or denied by means of running regression analysis. The model which is analyzed in the current research examines the relationships between endogenous variable - executive compensation, and four exogenous variables - total revenue, return on net assets, earnings per share for year $t-1$ and market value added for year $t$-1 (MVA) - measure of risk-adjusted firm performance.

Thus, the following model is estimated:

$$
\begin{aligned}
& \log \operatorname{Comp}_{i, t}=\beta_{0}+\beta_{1} \log \operatorname{Re} v_{i, t-1}+\beta_{2} \log \left(1+\operatorname{RONA}_{i, t-1}\right)+\beta_{3} \log \left(1+\operatorname{Re}_{i, t-1}\right)+ \\
& +\beta_{4} \operatorname{LogMVA}_{i, t-1}+\varepsilon_{i, t}
\end{aligned}
$$

Where:

Dependent variable:

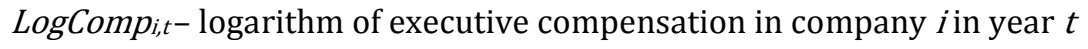




\section{Independent variables:}

LogRevit,-1 - logarithm of revenue in company $i$ in year $t-1$;

$\operatorname{LogRON} A_{i, t-1}$ - logarithm of RONA in company $i$ in year $t-1$;

$\operatorname{LogRe}_{i, t-1}$ - logarithm of earnings per share in company $i$ in year $t$-1;

$\log M V A_{i, t-1}$ - logarithm of MVA in company $i$ in year $t-1$;

$\varepsilon_{i}$ - error (unaccounted factors in a model).

Considering the model stated above (1) it could be predicted that executive compensation will be affected by accounting-based measures (revenue and RONA) and market-based measures (stock prices and market-value added). It is supposed that single group of measures will not be sufficient for explaining the earnings received by executive in a public corporation. Therefore, the combination of proxies is used.

In the current research the year 2004 is used as a basic year. Logarithms of all the variables are used because this transformation facilitates comparisons with the previous findings and reduces the skewness of the size distribution of the sample companies.

The first variable that was chosen is company's revenue. This measure is also used in the paper of Bebchuk and Grinstein (2005). Traditionally, the revenue is used as a measurement of the company's size. Thus, in the current research we will also consider revenue from the perspective of the company's size.

Vast majority of research papers devoted to executive compensation includes RONA: (Agarwal 1981; Belkaoui and Pavlik 1993; Deckop 1988; Kroll, Simmons and Wright, 1990; Leonard 1990). In the study of Bebchuk and Grinstein (2005) RONA is analyzed from the perspective of measurement that reflects the performance of the company. In the current research we also will use this approach. Thus, this variable will be interpreted from the point of the influence of company's performance on executive compensation. In the current research we use the following formula to calculate RONA for companies from our sample:

$$
\text { RONA }_{t}=\frac{{\text { Operating } \text { income }_{t}}_{\text {Net } \text { assets }_{t-1}}}{\text { ins }}
$$

Net assets in this case are defined as total assets less accounts payable (non-interest bearing liabilities).

The third variable that was chosen for the current research paper is earnings per share of a company. It also reflects the performance of the company. Murphy (1999) also used this variable to find out its relationship with executive compensation. The result of Murphy's study proved the existence of correlation between executive compensation and earnings per share.

And the last variable which is considered to be reasonably added is the market value added. In the study of Fatemi, Desai and Katz (2002) MVA was considered as a measure of risk-adjusted company's performance. He documents that executive compensation is positively related to the level of risk borne by the firm. He found out that the MVA to the firm is a significant determinant of executive compensation.

In the current research we use the following formula to calculate MVA for companies from our sample:

$$
\begin{gathered}
M V A_{0}^{R E}=\sum_{j-1}^{\infty} \frac{N I_{j}-k_{e} \times E_{j-1}^{B V}}{\left(1+k_{e}\right)^{j}} \\
k_{e}=R_{f}+\sum \beta \Delta R=R_{f}+\beta \times\left(R_{m}-R_{f}\right)
\end{gathered}
$$

Where:

$N I_{j}$ - net income in a year j;

$E_{j-1}^{B V}$ - book value of Equity for the beginning of the year;

$k_{e}$ - required return on equity;

$R_{f}$ - risk-free rate;

$R_{m}$-return on the market portfolio;

$\beta$ - beta-coefficient.

In the current research the yield to maturity of US governmental long-term bonds is used as a risk-free rate. For calculating beta-coefficient the stock prices and Dow Jones U.S. Telecommunications Index were used as all the companies from the sample are included in it. The information regarding stock prices was taken for 2004-2012 years. Return on the market portfolio was based on the total return for 9 years and as derived from the website of Dow Jones Indexes. 
We used monthly profitability of both variables. As calculates, beta-coefficient is -0.03 . It was calculated by two methods, using covariance and correlation. This means that the company was -0.03 that means that the stock is inversely correlated with the market. As it was described earlier it is necessary to run regression analysis for the period. In order to test the model and its components for significance Stata - data analysis and statistical software will be used.

\subsection{Data collection}

In the following section the process of data collection, sample and its parameters will be described. The sample of the current study had to satisfy the following criteria:

1. companies stocks are traded on New York Stock Exchange (NYSE) (in order for us to have access for the historical prices);

2. companies have to disclose information about executive's compensation: by components or in the form of total amount;

3. companies have to be included into Dow Jones U.S. Telecommunications Index (for us to do the MVA calculations).

As it is stated in the topic of current research, this study includes all companies from the telecommunications industry which are publicly-traded on NYSE. All the companies which were chosen had their IPO in 2004 or earlier. All the companies are headquartered in the United States of America. The final sample is comprised of 15 companies. The data is panel, because all the observations were collected for 9-years covering the period 2004 2012 and it will be not informative to estimate separate regression for each of the year.

In order to collect the data the following sources of the information were used:

1. Annual companies' statements which are issued to shareholders. The corporate proxy statements of form type DEF 14A were used to collect data about CEO compensation; the consolidated corporate annual reports of form type 10-K to collect data about the companies' Revenue, Operating Income, Net Assets, Equity and Net Income. The statements were collected through nyse.com using company's SEC filings, and when necessary corporate web-pages were used.

2. Databases - Lexis-Nexis Academic and Executive Pay Watch - and the webpage of New York Stock Exchange to collect data about CEO compensation.

3. Electronic source - djindexes.com to collect the historical returns for Dow Jones U.S. Telecommunications Index.

Table 01 represents the descriptive statistics for the sample. As it can be seen from Table 01 the executive compensation in telecommunications industry varied from \$487 637 to \$138455 450 for a sample of 15 companies obtained for the current research with the average compensation of $\$ 10006807.8$. This difference can be explained by different size of the US telecom companies that is represented by the next variable - Revenue. The bigger is a company, the more difficult it is to manage this company. And in this case CEOs ask for a higher compensation in order to cover higher efforts they have in order to manage bigger companies. The average Revenue for 9 years is $\$ 17052426.9$ with the change from 79708 to 124280000 . The average RONA for this period is $0,14 \%$, the average EPS in year $\mathrm{t}-1$ is $\$ 1,25$, the average changes in compensation in year t compared to year 0 is \$2 839 883.4. Market value added ranged from \$-105 296663 to \$1 954311.9 with the average of \$-3 410511 . Summarizing descriptive statistics we may say that the companies from the sample do not seem to be that profitable and, probably, well managed. The companies in the sample are considered to be quite large with average sales of \$17 052426.9 dollars annually.

\begin{tabular}{|c|c|c|c|c|}
\hline \multicolumn{5}{|c|}{ Table 01: Descriptive statistics of the sample } \\
\hline Variable & Mean & St Dev. & Minimum value & Maximum value \\
\hline Revenue, \$ & 17052426 & 31906799 & 79708 & 124280000 \\
\hline ROA, \% & 0.14 & 0,4 & -0.88 & 2.57 \\
\hline Earnings per share in year $t-1, \%$ & 1.25 & 3.06 & -0.97 & 14.28 \\
\hline Compensation, \$ & 10006807 & 14450274 & 487637 & 138455450 \\
\hline $\begin{array}{l}\text { Changes in compensation in } \\
\text { year } t \text { compared to year } 0 \$\end{array}$ & 2839883 & 5128958 & -10129041 & 15243556 \\
\hline MVA, \$ & -3410511 & 6424224 & -105296663 & 954311 \\
\hline
\end{tabular}

For the purposes of panel data analysis, the regression model was estimated with 3 steps: (1) comparison of models with the help of F-test; where we compared the ordinary test squares and fixed-effect (FE) model by F-test. The test revealed that the FE model is better, than OLS. In that model Prob. $>\mathrm{F}=0.0000$ which is less than 0.05 , therefore all the coefficients in the model are different from zero; (2) comparison of models with the help of Breusch-Pagan test. The results enable to say that the model with random-effects is better than the OLS model. (3) comparison of 
models with the help of Hausman test. The last step reveals the results of weighting the difference between the fixed-effects and random-effects vectors. From the random-effects estimator it might be predicted that the Hausman tests null hypothesis - random-effect is consistent - is soundly rejected. Thus, individual effects do appear to be correlated with the regressors. As Prob. $>$ chi $2=0.0000$, it may be said that the fixed-effects model is better than the random-effects model. So according to the results of the tests, a model with fixed effects was chosen as the most suitable.

It is also necessary to diagnose the model for multicollinarity. The results are presented below in Table 02 . We can make the conclusion that VIF is lower than 20 and $1 /$ VIF is higher than 0.05 , thus we may say that factors from the model are not collinear.

\begin{tabular}{lcr}
\hline & Table 02: Test for multicollinarity & \\
\hline Variable & VIF & 1/VIF \\
\hline LogRev & 1.58 & 0.634267 \\
\hline Log1RONA & 1.55 & 0.644394 \\
\hline Log1Re & 1.25 & 0.800693 \\
\hline LogMVA & 1.25 & 0.980064 \\
\hline Mean VIF & 1.28 & \\
\hline
\end{tabular}

\section{$5.0 \quad$ Results and discussion}

By using statistical package Stata the balance of the data panel was checked. To conduct the analysis it is necessary to follow the consequence of steps which were described above. The empiric research of comparison provides us with the following results (Table 03). Comparison of the results for ordinary test squares by F-test revealed that the fixed assets model is better, than OSL. In that model Prob. $>F=0.0000$ which is less than 0.05 , therefore all the coefficients in the model are different from zero.

\begin{tabular}{lcrr}
\hline & Table 03: Regression analysis results of fixed-effects model & Sig. \\
\hline Variables & Coef. & t-statistics & 0.000 \\
\hline LogComp & 0.5371989 & 3.66 & 0.466 \\
LogRev & -0.1440576 & -0.73 & 0.054 \\
Log1Re & 0.0763807 & 1.95 & 0.001 \\
LogMVA & -0.1339045 & -3.41 & 0.000 \\
cons & 3.955412 & 3.65 & \\
R-sq overall & 0.8614 & & \\
\hline \multicolumn{4}{c}{} \\
\hline
\end{tabular}

Thus, according to the obtained results the final regression equation may be constructed:

$$
\begin{aligned}
& \log \operatorname{Comp}_{i, t}=3.95+0.54 \log \operatorname{Re} v_{i, t-1}-0.44 \log \left(1+\operatorname{RON} A_{i, t-1}\right)+0.76 \log \left(1+\operatorname{Re}_{i, t-1}\right) \\
& -0.133 \log M V A_{i, t-1}+e_{i, t}
\end{aligned}
$$

In order to determine the extent of how well future outcomes are likely to be predicted by the model stated above the coefficient of determination $\mathrm{R}^{2}$ is used. For the current research it equals 0.8614 . Therefore, it may be concluded that this model may be used for describing executive compensation system. That means that $86 \%$ of changes in executive compensation are determined by joint change of revenue, return on net assets, earnings per share and market-value added. Other $14 \%$ are unexplained by the model.

Consideration of p-values revealed that for the model with fixed-effects significant factors are LogRev (0.0000), Log1Re (0.05) and LogMVA (0.001), their p-values are lower than 0.05. Examining further and considering the $t-$ values it is seen that LogRev and LogRe are more relevant than LogMVA as their t-values are higher than 1.96.

Summarizing the results obtained, it may be say that executive compensation for the current work does not depend on RONA and MVA as these factors appeared to be not significant. Factors that are significant are revenue and earnings per share; therefore we may conclude that partly the executive compensation is explained by accounting measures and partly by market measures. The obtained result coincides with the findings of McGuire, Dow and Argheyd (2003); Murphy (1985) and Roberts and Dowling (2002), i.e. there is a significant positive relationship between executive compensation and performance. That means that the higher the revenue of the company is the higher is the executive compensation and the higher earnings per share are, the greater is the remuneration of the executive. Thus, the hypothesis 1 and 3 are verified. This result could be also explained by the scale of the stock emission. Big corporations usually grant stock and options to CEO. According to Garen (1994) executive 
compensation in the form of stocks and options represents about $76 \%$ of total compensation, and evidently compensation in big corporations exceed the remuneration in smaller companies.

The fact that return on equity or RONA is insignificant for that model could be explained by the fact that nowadays companies use market proxies, not accounting as the indicators of company's success (Bebchuk and Grinstein; 2005). Even bonuses which theoretically have to depend on RONA are more often paid on the basis of market proxies (for example, increase of market capitalization). Also it may be assumed that executive compensation system in corporations is a motivational instrument, and thus are paid for previous achievements, but aimed at future results. All in all, hypothesis 2 that the higher RONA is, the greater is the remuneration of the executive is rejected. It is documented that MVA is not a significant determinant of executive compensation meaning that the companies do not pay the CEO for bearing risk. This contradicts our initial assumption. Thus, hypothesis 4 that the higher MVA is, the greater is the executive compensation is also rejected.

Using these results a set of recommendations could be developed which will enable companies to imply better corporate governance practices in their management process. The regression analysis has revealed that factors influencing executive compensation in US telecommunications industry are revenue and earnings per share. Therefore, it is important to deal with those managerial implications which could increase these two proxies.

Firstly, the accounting measure - revenue - has to be considered as it positively and significantly affects the executive compensation. Nowadays the growth in telecommunications industry is limited, it has even almost finished. The reason for this statement is the multiple SIM factors which mean that more than $100 \%$ of the population uses more than one SIM card and, consequently, telecommunications services. Nevertheless, some options which can stimulate the growth still exist. There are mainly two ways to increase the revenue in telecommunications industry: price reduction or volume increase. Let's consider both options.

One of the ways to decrease the price is to reduce the costs. In that case several possible recommendations could be proposed: (1) full cost transparency - will enable companies in telecommunications industry to identify, prioritize and optimize additional saving measures; (2) outsourcing - will enable companies to reduce the costs by subcontracting some functions, network operations and maintenance out to service providers; and (3) network sharing - will enable companies to substantially decrease capital expenses. This option comprises sharing of assets, operations or stuff sharing.

Another way to decrease the price is to introduce new offers. On this occasion, it could be recommended to telecommunications companies to develop novel pricing plans. This change will allow the companies to attract new subscribers, consequently leading to new sources of revenue in companies. Lower tariffs might also be, of course, a solution to the problem of high price; however, it is only short-term as the company which uses this tactic is likely to be involved in the tariffs wars and more likely to stop investing in new technology, quality of service and customer relationship. Therefore, the current research proposes to focus on cost reduction and designing new offers or pricing plans.

The other direction to be worked out in order to increase the revenue is dealing with the volume issue. Here two ways could be considered: dealing with churn rate and customers. Churn rate is one of the greatest issues in the telecom sector. It is all about the stability of customer base in a particular company. Thus, the main challenge here is to retain the existed subscribers, reducing the number of those who switched to another operator; or increasing the number of new subscribers so that it could exceed the number of customers who left.

In order to retain the existed customers designing the novel loyal system of bonuses or offers for existed customers could be suggested. The main goal of this approach is to establish mutually beneficial and long-lasting relationships with a client. This could be done by analysis of the values and needs of subscribers, i.e. by optimization of the interaction processes between clients and company (for example, in case of technical problems), by improvement of the efficiency of technological processes or introduction the Key Performance Indicator (KPI) systems.

The second part of volume of services increase issue is dealing with customers. On this occasion companies may consider several options:

1. Strategic mergers and acquisitions - will enable telecom companies to consolidate their efforts towards growth stimulation and achieve the scale efficiency. The merged companies would gain the larger market share, the access to new markets and new customers. This option may also eliminate the competition and increase the efficiency of exploiting new opportunities.

2. Promotion campaigns - will enable companies to attract more subscribers with the help of different promotion events and advertising campaigns.

3. Offers of mobile specific content - will enable companies to attract new segment of subscribers by including video, TV or internet services into the service portfolio of a company. 
4. Market expansion - will enable companies to expand geographically, thus it is a good option to reach new customers.

5. Development of new mobile applications for enterprise segments - will enable companies to attract large industrial segments which could use this application in monitoring, controlling or data entry (ex., SAP data entry).

The second proxy could contribute to executive compensation according to the results of the current research is earnings per share. Evidently, due to the fact that EPS is directly depend on the amount of net income, we could conclude that in order to increase EPS a company has to increase its revenue (considered earlier) or decrease the number of shares by buyout them from the shareholders.

Another way to increase the value of EPS is to deal with financial leverage, effective implication of which leads to the increase in net income and returns. Positive net income in that case is formed from the debt not from the equity due to the tax shield because the interest is paid from the revenue. However, using financial leverage implies big risks, primarily those that the company will be unable to pay out its debt. Objective evaluation of risks, its mitigation and effective financial leverage management are the main responsibilities of managers in contemporary companies. Therefore, managing two proxies in the ways described above will contribute to the executive compensation growth, thus, as a consequence, to the elimination of agency problem, because in that case managers will not have an incentive to act irresponsibly and in self-interests.

\subsection{Conclusion and policy implication}

The previous section has revealed that three out of five hypotheses is verified by the current research. Table 04 presents the summary of hypotheses tests.

\begin{tabular}{clcc}
\hline & & \multicolumn{2}{c}{ Table 04: Summary for hypothesis test } \\
\hline Hypothesis & & Formulation & Result \\
\hline 01 & The higher is the company's revenue, the greater is the executive remuneration. & Verified \\
\hline 02 & The higher is ROA, the greater is the remuneration of the executive. & Denied \\
\hline 03 & The higher are earnings per share, the greater is the executive compensation. & Verified \\
\hline 04 & The higher is the market value added, the greater is the executive compensation. & Denied \\
\hline
\end{tabular}

For the purposes of the paper the corporate governance concept was investigated from the perspective of agency problem and executive compensation. The primary conclusion of this paper is that executive compensation depends on the company's performance since current research revealed that revenue and earnings per share are strongly and positively related to it. Therefore, the higher the revenue and earnings per share are in the company the higher is the executive compensation. That means that every decision made by executive in order to maximize the shareholder value does influence the amount of his compensation. Therefore, companies could use executive compensation system as an effective mechanism to eliminate the agency problem and, consequently, agency costs.

In the current research the insignificant factors are return on net assets and market value added. This fact contradicts our initial assumptions but could be explained by the fact that nowadays companies use market proxies, not accounting as the indicators of companies' success, but still are not ready for paying the CEO for the risk bared. The current work paper is a basis for further research which will aim at optimization of the mechanisms of corporate governance. One of the proposed directions for further research which may support the current work could be based on execution of individual influence of salary, bonus, option awards, deferred compensation and value of stock options on the total executive compensation. In addition to this, more variables could be included in the model.

The current research could be conducted on a larger sample in the future that is one of the limitations of the paper. The comparison of factors that influence executive compensation in telecommunication companies in developed and developing countries could be also of high interest. Even though there are some limitations, the evidence of this research on the relation between compensation and accounting and market measures will enhance the knowledge on the role of factors that influence the executive compensation system and help develop a strategy to eliminate the agency problem in telecommunications industry.

\section{References}

Adjaodi F., Zeghal D., Andaleeb S., 2007. The effect of board quality on performance: a study of Canadian firms. Corporate Governance, 2: 145-183.

Agarwal N. 1981., Determinants of executive compensation. Industrial Relations, 1: 36-45. 
Baum C.L., Sarver L., Strickland T., 2004. EVA, MVA and CEO Compensation: further evidence. American Business Review, 22(2): 82-87.

Bayburina E., Shustrova Y., 2008. Influence of executive compensation on valuation of Russian corporations. Corporate Finance, 4(8): 60-79.

Bebchuk L. A., Fried J.M., 2004. Pay Without Performance: The Unfulfilled Promise of Executive Compensation. Harvard University Press. UC Berkeley Public Law Research Paper No. 537783.

Bebchuk L., Grinstein Y., 2005. The growth of executive pay. Oxford Review of Economic Policy, 2: 283-303.

Beer M., Katz, N., 1998. Do incentives work? The perceptions of senior executives from thirty countries. Harvard Business School Working Paper.

Belkaoui A., Pavlik E., 1993. Effects of ownership structure, firm performance, size and diversification strategy on CEO compensation: A path analysis. Managerial Finance, 19(2): 33-54.

Black B., Jang H., Kim W., 2005. Does corporate governance predict firms' market values? Evidence from Korea. Journal of Law, Economics and Organization, 2: 660-691.

Deckop J. R., 1988. Determinants of chief executive officer compensation. Industrial and Labor Relations Review, 2: 215-226.

Fatemi A., Desai A., Katz J., 2002. Wealth creation and managerial pay: MVA and EVA as determinants of executive compensation. Global Finance Journal, 14: 159-179.

Ferris S.P., Murali J., Pritchard A. C., 2003. Too busy to mind the business? Monitoring by directors with multiple board appointments. The Journal of Finance, 58: 1087-1112.

Florin B., Hallock K.F., Webber L.D., 2010. Executive pay and firm performance: methodological considerations and future directions. Research in personnel and human resources management, 29: 49-86.

Garen J.E., 1994. Executive compensation and principal-agent theory. The Journal of Political Economy, 102(6): 1175-1199.

Hall B.J, Liebman J.B., 1998. Are CEOs really paid like bureaucrats? The Quarterly Journal of Economics, MIT Press, 113(3): 653-691.

Hambrick D.C., Finkelstein S., 1995. The effects of ownership structure on conditions at the top: the case of CEO pay raises. Strategic Management Journal, 16(3): 175-193.

Hermalin B., Weisbach M., 1988. The determinants of board composition. Journal of Economics, 4: 589-606.

Junarsin E., 2011. Executive compensation and firm performance: an empirical examination. European Journal of Economics, Finance and Administrative Sciences, 28: 163-179.

Kroll M., Simmons S. A., Wright P., 1990. Determinants of chief executive officer compensation following major acquisitions. Journal of Business Research, 20: 349-366.

Lawrence J., Stapledon, G., 1997. Do independent directors add value? Research report. Centre for corporate law and securities, the University of Melbourne. Available at: http://mjil.law.unimelb.edu.au/files/dmfile/IndependentDirectorsReport2.pdf

Leonard J. S., 1990. Executive pay and firm performance. Industrial and Labor Relations Review, 43(3): 13-29.

McGuire J., Dow S., Argheyd K., 2003. CEO incentives and corporate social performance. Journal of Business Ethics, 45(4): 341-359.

Mehran H., 1995. Executive compensation structure, ownership and firm performance. Financial Economics, 2: 163-184.

Murphy K. J., 1985. Corporate performance and managerial remuneration: an empirical analysis. Journal of Accounting and Economics, 7: 11-42.

Murphy K. J., 1999. Executive Compensation, Handbook of Labor Economics, Orley Ashenfelter and David Card, eds. Amsterdam: North Holland.

Roberts P.W., Dowling, G., 2002. Corporate reputation and sustained superior financial performance. Strategic Management Journal, 23(12): 1077-1093.

Rosenstein S., Wyatt J. G., 1990. Outside directors, board independence, and shareholder wealth. Journal of Financial Economics, 26(2): 175-191. 